Arie W. Zwiep

\title{
Jairus's Daughter and the Haemorrhaging Woman
}

\author{
Tradition and Interpretation of an Early Christian Miracle Story
}

[Jairus' Tochter und die blutflüssige Frau. Tradition und Interpretation einer frühchristlichen Wundererzählung.]

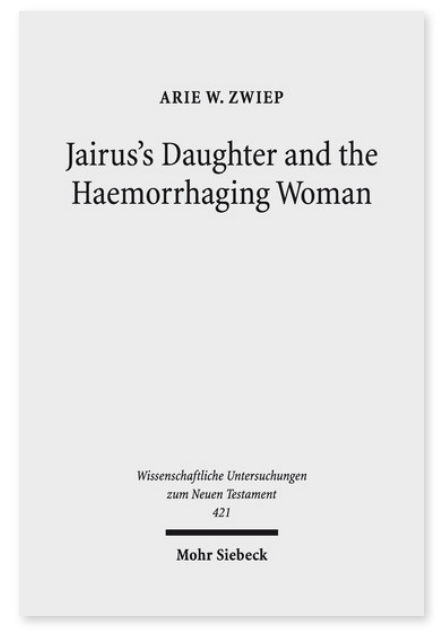

Published in English.

In this work, Arie W. Zwiep examines the gospel stories of the raising of Jairus's daughter and the healing of the haemorrhaging woman (Mark 5:21-43; Matt 9:18-26; Luke 8:40-56) from a plurality of (sometimes conflicting) interpretive strategies to demonstrate the need and fruitfulness of a multi-perspectival exegetical approach. Among the various (diachronic and synchronic) methods that are being applied in this study are philological criticism, form criticism and structural analysis, tradition- and redaction criticism, orality studies and performance criticism, narrative analysis, textual criticism and the study of intertextuality. Such a comprehensive approach, it is argued, leads to an increased knowledge and a deepened understanding of the ancient texts in question and to a sharpened awareness of the applicability of current scholarly research instruments to unlock documents from the past.

Arie W. Zwiep Geboren 1964; 1996 Promotion; 2017-20 Director Graduate School of Religion and Theology an der Fakultät Religion und Theologie der Vrije Universiteit Amsterdam; dort seit 2020 Prodekan, seit 2021 Professor für Hermeneutik. https://orcid.org/0000-0003-0126-1563

2019. XXVI, 454 pages. WUNT I 421

ISBN 978-3-16-157560-0

cloth $159,00 €$

ISBN 978-3-16-157561-7

eBook PDF 159,00€

\section{Order now:}

https://www.mohrsiebeck.com/en/book/jairuss-daughter-and-the-haemorrhaging-woman-9783161575600?no_cache=1 order@mohrsiebeck.com

Phone: +49 (0)7071-923-17

Fax: $+49(0) 7071-51104$ 